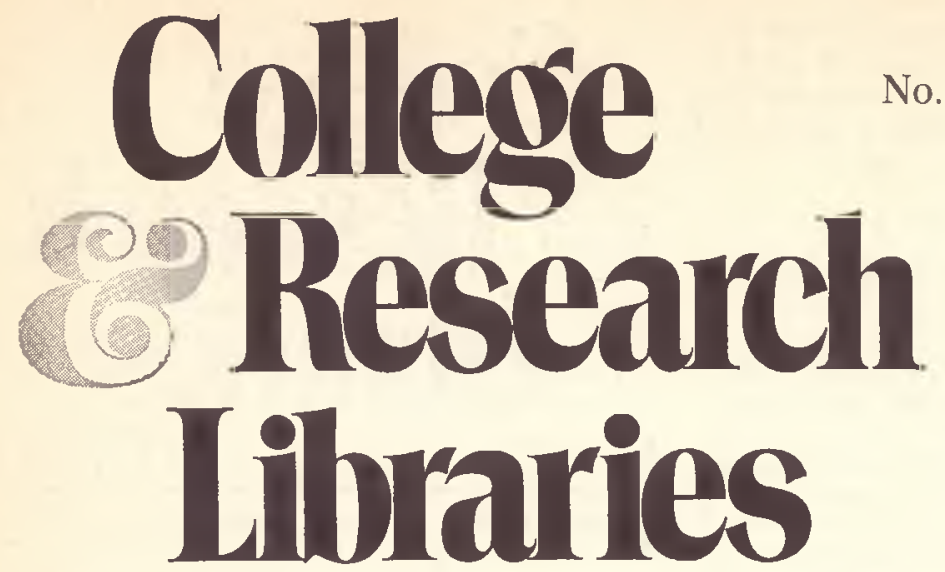

No. 8, September 1970

ACRL News Issue (A) of College \& Research Libraries, Vol. 31, No. 5

\title{
ACRL Membership Meeting Favors Federation
}

To the ACRL Membership:

Those who were at Detroit are now well aware of the contents of the final report of the ALA Committee on New Directions, and of the differing and seemingly irreconcilable views on those recommendations. If you were not at the ALA Conference, you should make a point of reading the ACONDA report, which will be made available in the near future. You should also follow, in the library periodicals, the accounts of the membership meetings in order to get some indication of the frustrations, bitterness and divisions amongst the members at Detroit. It was a deeply disturbing experience.

ACRL's Planning Committee and Board of Directors recommended support of the democratization proposals in the ACONDA report, and implementation, as soon as possible, of the first long range ACONDA recommendation, namely for federation. The Committee and Board also favored a type of library, rather than a type of activity, form of organization. They felt that no formal recommendation on reorganization could be made until after the preparation of position papers which would propose a possible organizational structure; identify the goals, directions, and responsibilities of ACRL as a federated component of ALA; and determine the financial implications.

This report was presented to the ACRL membership meeting for open discussion. The sense of the meeting supported the views of the Planning Committee and the Board of Directors. The ACRL Executive Committee, therefore, will be working on a statement for presentation to the new committee to which ACONDA is now to report back. We will also be appointing a committee to develop the suggested position papers.

However, we recognize that only a small proportion of the total membership of either ALA or ACRL attends the annual conferences. Before we speak for ACRL membership we would like opinions from as wide a representation as possible and for this reason are including in this issue of CRL News the pertinent documents. We ask, therefore, that you send your views to any of us listed below. No final commitment to reorganization on the part of ACRL will be made without a mail vote of the membership.

Anne C. Edmonds, President Philip McNiff, Past President Joseph Reason, President-Elect J. Donald Thomas, Executive Secretary

\section{American Library Association REORGANIZATION}

Academic libraries, as well as other types of libraries, are institutions having a configuration of problems which make them unique institutions in terms of priorities, personnel, and pro- 
fessional aims. Failure to recognize this principle and gear the reorganization of ALA to respond to this particular set of requirements would produce general mediocrity throughout the work of the association.

It is therefore recommended that:

I. ALA become a federation of library associations with a strong central headquarter's secretariat.

II. Each of the federated associations determine policy in all matters concerning its areas of interest.

III. ACRL as a federated association be headed by an executive director appointed by the Association of College and Research Libraries. The executive director is responsible to the membership of the association and is responsible for executing policies and programs initiated by the membership, providing staff and setting salaries.

IV. Membership in ACRL be open to individuals holding a library degree or individuals who by their professional appointment may be designated as having rank equivalent to one holding such a degree.

V. Membership dues be collected by ACRL with not more than 20 percent allocated to support the ALA secretariat.

VI. The officers of the federated associations form an executive committee to the ALA secretariat staff. Meetings of this executive committee should be frequent, and task forces (with terminal dates) should be appointed by this advisory body to study interdivisional problems.

VII. Among the responsibilities of the ALA secretariat be the maintenance of central offices offering various professional and administrative services to the federated association. The advisory group to each office should be composed of representatives appointed by each of the federated associations and should have the responsibility of reporting back to the parent association.

Submitted by: ACRL Planning Committee 29 June 1970

Passed by: ACRL Membership and ACRL Board of Directors

June 1970

\section{ACRL Membership}

July 31,1970

July 31,1969

13,171

July 31,1968

12,604

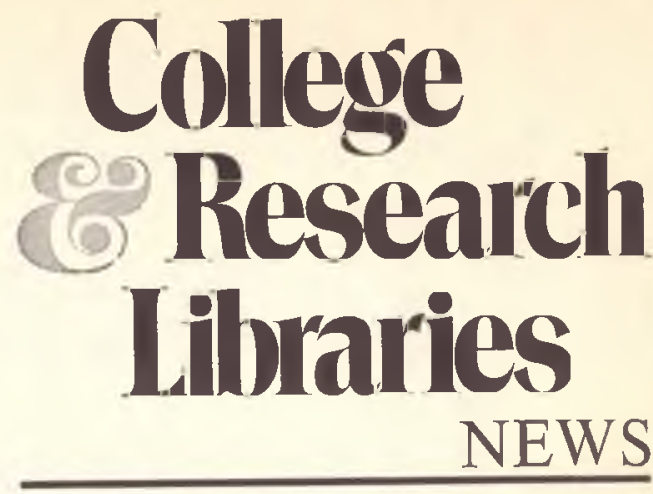

News Editor, Michael Herbison, Casper College, Casper, Wyoming 82601.

Editor, Richard M. Dougherty, School of Library Science, Syracuse University, Syracuse, New York 13210.

Editorial Board: William AxFond, Arizona State University; Richard DE Gennaro, University of Pennsylvania; Fred J. Hensatz, Southern Connecticut State College; David Heron, University of Kansas; Peter Hiat, Western Interstate Commission for Higher Education, Boulder, Colorado; Ellsworru G. MAson, Hofstra University.

ACRL Officers, 1970/71: President, Anne C. Edmonds; Chairman, College Libraries Section, Carl H. Sachtleben; Junior College Libraries Section, Mrs. Joleen Bock; Rare Books Section, Julius P. Barclay; Subject Specialists Section, Eleanor Buist; Agricultural and Biological Sciences Subsection, Joseph C. Shipman; Art Subsection, Peter Anthony; Asian and North African Subsection, Joyce Wright; Education and Behavioral Sciences Subsection, Dr. Sidney Forman; Law and Political Science Subsection, Dr. Otto G. Gara; Slavic and East European Subsection, Dr. Ivan L. Kaldor; University Libraries Section, David W. Heron.

News from the Field, Personnel profiles and notes, classified advertising, official matter of ACRL, and other material of a timely nature is published in the News issues of College \& Research Libraries.

Inclusion of an article or advertisement in $C R L$ does not constitute official endorsement by ACRL or ALA. Production and Advertising and Circulation office: 50 E. Huron St., Chicago, Ill. 60611. Change of address and orders for subscriptions should be addressed to College $\&$ Research Libraries, for receipt at the above address, at least two months before the publication date of the effective issue.

Subscription to CRL is included in membership dues to $A C R L$ of $\$ 6$ or more; other subseriptions to $C R L$ are $\$ 10$ per year. Neither subscriptions nor memberships include miscellaneous unscheduled supplements, which are available by purchase only. Retroactive subscriptions are not accepted. Single journal copies are available at $\$ 1.50$ each and News issues at $\$ 1.00$ each from ALA Publishing Department.

Indexed in Current Contents, Library Literature, and Science Citation Index. Abstracted in Library Science Abstracts. Book reviews indexed in Book Review Index. College \& Research Libraries is the official journal of the Association of College and Research Libraries, a division of the American Library Association; and is published seventeen times per year-bi-monthly as a technical journal with 11 monthly News issues, combining July-August-at 1201-05 Bluff St., Fulton, Mo. 65251 .

Second-class postage paid at Fulton, Mo. 